\title{
13
}

\section{Crowdfunding Prospects in New Emerging Markets: The Cases of India and Bangladesh}

\author{
Krishnamurthy Suresh, Stine Øyna, \\ and Ziaul Haque Munim
}

\section{Introduction}

In 2013, the World Bank published a report on crowdfunding's potential in emerging markets, which estimated a market opportunity for South Asia alone of close to USD 5 billion (The World Bank 2013). The South Asia region consists of predominantly collectivist societies (Hofstede Insights 2019)—India, Bangladesh, Sri Lanka, Pakistan, Bhutan, and Nepal-where helping others through donations is an integral part of

K. Suresh $(\bowtie)$

Indian Institute of Management Bangalore (IIM B), Bangalore, India

S. Øyna

School of Business and Law, University of Agder, Kristiansand, Norway e-mail: stine.oyna@uia.no

Z. H. Munim

Faculty of Technology, Natural Sciences and Maritime Sciences, University of South-Eastern Norway, Horten, Norway

e-mail: Ziaul.H.Munim@usn.no 
prevailing religious obligations and societal norms. Thus, these countries share certain cultural and religious traits that are highly consistent with the principles of crowdfunding. Yet, by 2017, the alternative finance activity in the region amounted to no more than USD 269 million, 96\% of which was related to the Indian market (see Table 13.1), indicating a vast untapped potential in the Asian economies.

In the current chapter, we explore the history, ongoing activity, and future prospects of crowdfunding in new emerging markets. Specifically, we look into the cases of India and Bangladesh. Both countries represent interesting crowdfunding markets due to the cultural inclinations described above, combined with their large populations (1.3 billion people in India and 165 million in Bangladesh) and number of people living in extreme poverty (15\% of the population in Bangladesh and $21 \%$ in India) (The World Bank 2019). India is, by far, the leading market of alternative finance in the South Asia region, and thus provides an interesting case to explore. The alternative finance market in Bangladesh, on the other hand, is still in its infant stage and thus far less developed. Comparing and contrasting the state and types of crowdfunding in these two markets thus allow us to reach new insights.

The remainder of this chapter consists of sections focusing on India and Bangladesh, respectively. Both sections cover the history, including cultural roots of crowdfunding in the given market, prevailing models and platforms, regulatory issues, and future prospects. Given the relatively more developed state of crowdfunding in India versus Bangladesh, the section on India is naturally more comprehensive. The chapter concludes with a few summarizing remarks on the state of crowdfunding in new emerging markets.

Table 13.1 Alternative finance volume in South Asian countries

\begin{tabular}{llll}
\hline Country & Volume (USD) $^{\mathrm{a}}$ & Population $(\mathrm{M})^{\mathrm{b}}$ & Volume per capita $^{\text {B }}$ \\
\hline Bangladesh & 10,272 & 161 & 0.0001 \\
Bhutan & 10,000 & 0.8 & 0.0133 \\
Nepal & $1,014,850$ & 28 & 0.0361 \\
India & $268,579,820$ & 1352 & 0.1986 \\
Pakistan & $8,571,762$ & 212 & 0.0404 \\
Sri Lanka & 38,926 & 21 & 0.0018 \\
\hline
\end{tabular}

aZiegler et al. (2018)

${ }^{\mathrm{b}}$ The World Bank database 


\section{Crowdfunding in South Asia}

Research on crowdfunding in South Asia is still somewhat limited, although a few contributions do exist. Crowdfunding studies in the Indian context examine regulatory issues (Marakkath and Attuel-mendes 2015), business model transformation (Srivastava 2016; Chirputkar et al. 2015; Gupta and Bose 2019), risk factors (Leela 2016), crowdfunding intention (Baber 2019a), and drivers of growth (Pa 2018). Similarly, studies in the Bangladeshi context examine crowdfunding business model (Adhikary and Kutsuna 2016), awareness and drivers of crowdfunding (Adhikary et al. 2018), and the drivers of crowdfunding intention (Hasan et al. 2018; Munim et al. 2020). In sum, these studies build knowledge relating to crowdfunding on the individual (backer), firm, and societal levels.

Until 2014, a few crowdfunding platforms were operational in India, and people believed that family or friends or venture capital firms would determine crowdfunding campaign success (Srivastava 2016). A majority of the early platforms were associated with creative industries like filmmaking, publishing, and design (ibid.). On the contrary, in 2019, the existing Bangladesh crowdfunding platforms are not fully functional but are more dedicated to raising funds for medical treatment or equity (Munim et al. 2020). In both the Indian and Bangladeshi context, the main drivers of crowdfunding are increased demand for alternative finance due to improved socio-economic status, significant increase of internet users, complexity of documentation, and requirement for tangible securities for credit applications in traditional financial institutions such as banks (Srivastava 2016; Adhikary et al. 2018; Marakkath and Attuel-mendes 2015).

In terms of factors influencing crowdfunding intention, findings are similar in the Indian and Bangladeshi contexts. For instance, technological awareness and experience of traditional financial market have a positive influence on a backer's crowdfunding intention (Baber 2019b; Hasan et al. 2018). Meanwhile, in societies like India and Bangladesh which can be "characterized by a low degree of thin trust between strangers, people are less willing to contribute to/invest in fundraising efforts by a stranger" (Kshetri 2015, p. 106). Therefore, the campaign owner being friends and 
family is positively associated with a backer's crowdfunding intention in the Indian context (Baber 2019a). However, the quality of the campaign and media coverage is more important in the Bangladesh context (Munim et al. 2020).

\section{Crowdfunding in India}

\section{History}

Crowdfunding or crowdsourcing, in various forms and under various names, has existed in India since ancient times. For instance, 'Chanda' involves people collecting small sums of money from large crowds to finance religious, cultural, and other events like festival celebrations in the local community. Another example of a historic crowdfunding campaign happened in 1962, during the war with China. The then Indian Prime Minister, Jawaharlal Nehru, appealed to the citizens of the country to contribute to the defence fund. Thousands of people, especially women, donated not only money but also their jewellery. The campaign was said to have collected over USD 220,000 in cash and much more in gold. Later, in 1976, a group of 500,000 milk farmers from the Indian state Gujarat contributed to fund the movie 'Manthan,' which was estimated around INR 1.1 million (USD $1 \approx$ INR 70). After the inception of modern-day (internet-based) crowdfunding, the Indian online crowdfunding started its operations in 2012 with the launch of Wishberry, Ketto, and Milaap (Impact Guru 2017).

\section{Prevailing Models and Platforms}

The four prevailing models of crowdfunding — reward, equity, lending, and donation - are all represented in the case of India, and Fig. 13.1 presents their levels. Loan-based crowdfunding is responsible for the majority of the activity. Since 2016, equity and donation-based crowdfunding have reached similar levels. The volume of reward-based crowdfunding, however, remains low. The different types of crowdfunding in the Indian context are discussed below. 


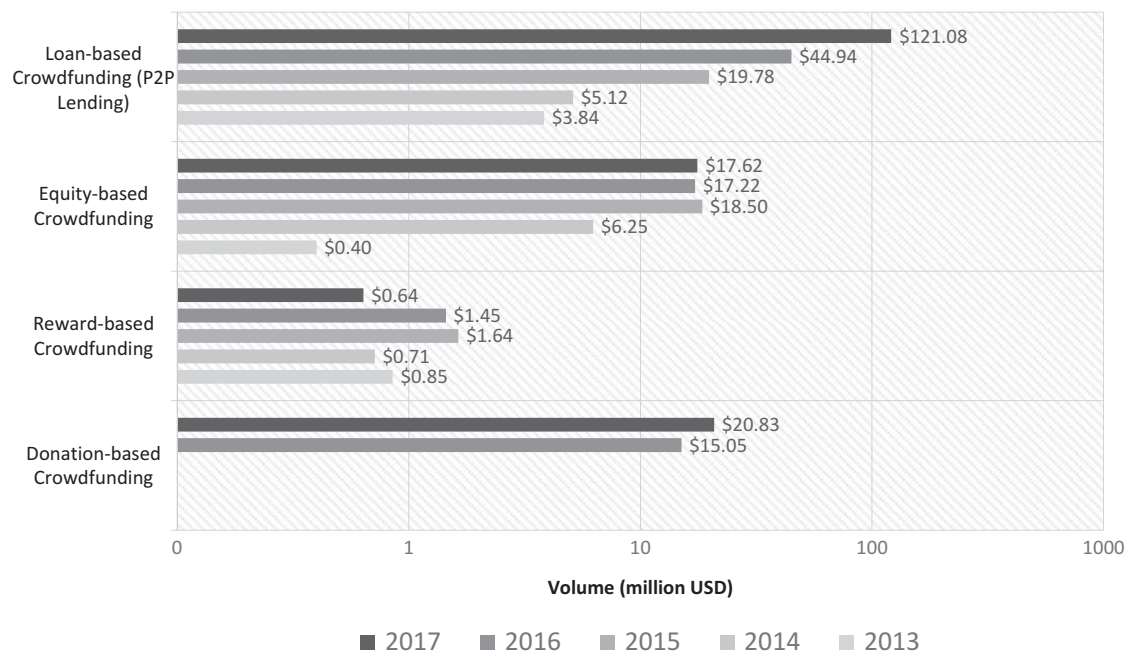

Fig. 13.1 Indian crowdfunding market volumes by model (2013-2017). (*Based on figures from Ziegler et al. [2018])

\section{Donation-Based Crowdfunding}

Philanthropy—including charity and donations-is an integral part of the Indian culture and tradition, visible through its mention in the first Indian scripture-known as Vedas (Bhasin 2019). In India, the word 'donation' or 'giving' has different nomenclature based on religion. The Hindus term it as daana (giving) and dakshina (alms), Buddhists call it as Bhiksha (alms), while it is zakat (prescribed offerings) and sadaqah in Islam (Viswanath and Dadrawala 2004). As per classical Hinduism, it is considered as the duty of an individual to help those who are in need (Bornstein 2009). Donations are usually made for social, religious, cultural, as well as political causes. Earlier, donation was an individual activity. However, the establishment of socio-religious institutions during the nineteenth century gave birth to scientific or institutional philanthropy, which is later dominated by NGOs, trusts, and foundations.

Donation-based crowdfunding is the second-largest model by volume after P2P lending in India. Around USD 21 million were raised in 2017 (see Fig. 13.1), and, as of May 2019, there are more than 25 
donation-based (Table 13.2) crowdfunding platforms operating. Campaigns on these platforms allow both individuals and NGOs to raise money in support of various causes under categories such as health, education, community development, and others.

Table 13.2 List of popular donation and reward-based crowdfunding platforms in India

\begin{tabular}{|c|c|c|c|c|}
\hline Platform & Website & Model & Foundation & Commission $^{a}$ \\
\hline $\begin{array}{l}\text { Desired } \\
\text { Wings }\end{array}$ & $\begin{array}{l}\text { desiredwings. } \\
\text { com }\end{array}$ & Reward & 2015 & $10 \%$ \\
\hline Dreamwallets & $\begin{array}{l}\text { dreamwallets. } \\
\text { com }\end{array}$ & Reward & 2015 & $\begin{array}{l}5 \% \text { (9\% under } \\
\text { Keep What } \\
\text { You Get } \\
\text { (KWYG) } \\
\text { model) }\end{array}$ \\
\hline EduDharma & $\begin{array}{l}\text { edudharma. } \\
\text { com }\end{array}$ & Donation & 2017 & $5 \%$ \\
\hline Fueladream & $\begin{array}{l}\text { fueladream. } \\
\text { com }\end{array}$ & Donation + Reward & 2016 & $\begin{array}{l}\text { Normal } \\
\text { campaigns } \\
6 \% \text { and } \\
\text { group } \\
\text { campaigns } \\
9 \%\end{array}$ \\
\hline Givelndia & giveindia.org & Donation & 2000 & $5-10 \%$ \\
\hline ImpactGuru & $\begin{array}{l}\text { impactguru. } \\
\text { com }\end{array}$ & Donation & 2014 & $\begin{array}{l}\text { Self-driven: } \\
5 \% \text { for } \\
\text { individuals } \\
\text { and social } \\
\text { enterprises, } \\
3 \% \text { for } \\
\text { NGOs; } \\
\text { Accelerate: } \\
12 \%\end{array}$ \\
\hline Ketto & ketto.org & Donation & 2012 & $5-6 \%$ \\
\hline Milaap & milaap.org & Donation & 2010 & $5 \%$ \\
\hline Wishberry & wishberry.in & Reward & 2012 & $10 \%$ \\
\hline Gocrowdera & $\begin{array}{l}\text { gocrowdera. } \\
\text { com }\end{array}$ & Donation + Reward & 2014 & $0 \%$ \\
\hline
\end{tabular}

aFees excluding processing charges, GST, and payment gateway charges. Data compiled from platform websites (as of May 21, 2019) 
A popular form of donation-based crowdfunding in India is nonmonetary donations, where backers donate products, meals, or medicine to people in need. Donatekart is one such platform that enables backers to donate various products to the NGOs which they wish to support. Another platform, Give India, enables backers to support the delivery of midday meals to poor children across the country through one of their initiatives-Mission 10 Million Meals. Finally, in the last two to three years, medical crowdfunding has taken off in India, where platforms like Milaap, Ketto, and ImpactGuru assist common people in raising money for expensive medical treatments. Given the population and poverty levels of the country, these forms of non-financial return crowdfunding have the potential to make a substantial socio-economic impact.

\section{Reward-Based Crowdfunding}

In the case of reward-based crowdfunding, backers receive a non-financial reward in return for the money contributed: as of May 2019, about nine to ten reward-based platforms were operating in India (including reward + donation, see Table 13.2), the most prominent ones being Wishberry and Fueladream. Noteworthy, some of the campaigns on Fueladream are run by students raising funds for social causes. For example, one such campaign ran by students, aimed at raising funds to help with the education of children from underprivileged homes, has been funded 534 times (Goal: INR 1,080,000). Also, platforms like Desired Wings and Rug Beneath My Feet are exclusive women-centric platforms. As per Ziegler et al. (2018), around USD 5.3 million has been raised by these platforms over the years from 2013 to 2017 (see Fig. 13.1) of which $40 \%$ of the fundraising was for business purposes.

\section{Equity-Based Crowdfunding}

India has developed into a start-up hub with the third-largest start-up ecosystem in the world, home to more than 20,000 start-ups (KPMG 2018), more than 63 million micro, small, and medium enterprises 
(MSMEs) (Government of India 2017) and more than 210 active incubators/accelerators (NASSCOM 2018). Traditionally, start-ups are being funded through angel investors, private equity, or loan arrangements with banks and other financial institutions. However, since the global financial crisis of 2008, financing through traditional means became even more challenging, resulting in a credit gap where nearly 50 million MSMEs have an unmet debt demand of USD 198 billion (PWC 2018). In line with the rapid growth in the number of established start-ups, alternative means of financing these enterprises evolved.

Under equity crowdfunding, the equity shares of the company are issued to the investors in consideration for their investment. There are around 15 such platforms operating in India (as of May 2019), LetsVenture being the most prominent one (see Table 13.3). The platform has more than 4400 angel investors and has funded over 172 deals. By 2016, around 200 companies had been crowdfunded by equity-based platforms, and the total amount raised was over INR 3.5 billion. The average ticket size for small working capital was between INR 5 million and INR 60 million, while average fund-raised ticket size was between INR 30 and 40 million (Menon 2016). However, the regulatory challenges for equity crowdfunding have curbed the growth prospects of the industry. As per Ziegler et al. (2018), around USD 60 million has been raised by these platforms over the years, from 2013 to 2017 (see Fig. 13.1).

Table 13.3 List of popular equity crowdfunding platforms in India

\begin{tabular}{lll}
\hline Platform & Website & Foundation \\
\hline 1Crowd & 1crowd.co & 2015 \\
Ah! Ventures & ahventures.in & 2009 \\
ANGLEPaisa & anglepaisa.com & 2015 \\
Coseeding & coseeding.com & 2016 \\
Enablers & enablersinvestment.com & 2014 \\
Grex & grex.in & 2014 \\
LetsVenture & letsventure.com & 2013 \\
SpicyFunds & spicyfund.com & 2011 \\
ientra & ientra.com & 2016 \\
\hline
\end{tabular}

Commission information of most of the equity crowdfunding platforms is not publicly available 


\section{Lending-Based Crowdfunding (Peer-to-Peer Lending)}

Alternative lending is one of the fastest-growing segments in the Indian Fintech space, reflecting the unmet financial needs of Indian consumers and businesses. Over $40 \%$ of the population and around $90 \%$ of small businesses are not linked to formal financial institutions (EY 2017). Also, nearly $90 \%$ of the consumer market is unaddressed by the existing financiers due to insufficient credit scores (ibid.). The failure of banks and other financial institutions to meet the needs of these segments, especially after the global crisis, led to the rise of alternative lending in India. As of 2017, there were more than 225 alternative lending companies in India (ibid.).

Like other emerging economies, the country has multiple informal sources of financing for the unbanked population, like chit funds and microfinance. Chit funds are schemes that combine savings and credit (Kapoor et al. 2012). Chit funds could be registered or unregistered, organized by formal financial institutions or informal groups such as friends and relatives. In India, there are more than 10,000 registered chit funds and around 200,000 unregistered ones. The value of the unregistered chit fund industry is estimated to almost 100 times the registered value, which is about INR 300 billion (Acharya 2013).

In India, though still in a nascent stage, P2P is one of the fastestgrowing markets, with current market size of around INR 2 billion, including both consumer and business loans (Saleem 2018). The market is expected to reach over USD 5 billion by 2020 (Deloitte 2017). There are currently between 40 and 50 platforms operating under the P2P model, although only 11 are registered with the Reserve Bank of India, so far. The most prominent P2P platforms are Faircent, Finzy, Lendenclub, and Monexo. The interest rates on these platforms are generally categorized based on the riskiness of loans (i.e. low risk-ultra high risk, and 'unidentified'), range between 14 and 36\% (over 40\% for unidentified).

In addition to providing an attractive asset class for lenders, the P2P industry acts as an avenue for financial and credit inclusion through addressing underserved people and small businesses. Mostly, the borrowers of the industry are from tier-two and tier-three locations, who would 
Table 13.4 List of RBI registered peer-to-peer lending platforms in India

\begin{tabular}{|c|c|c|c|c|}
\hline No & Platform & Website & Foundation & Interest rates \\
\hline 1 & Cash Kumar & cashkumar.com & 2014 & $18-30 \%$ (flat) \\
\hline 2 & Monexo & monexo.co/in & 2016 & $\begin{array}{l}12-30 \% \text { (for salaried } \\
\text { loans) }\end{array}$ \\
\hline 3 & Faircent & faircent.com & 2013 & $\begin{array}{l}12-28 \% \text { (excluding } \\
\text { unrated borrowers) }\end{array}$ \\
\hline 4 & Peerlend.in & peerlend.in & 2015 & $14-36 \%$ \\
\hline 5 & AnyTimeLoan.in & anytimeloan.in & 2014 & $\begin{array}{c}\text { Interest as low as } \\
0.05 \% \text { per day }\end{array}$ \\
\hline 6 & ¡2ifunding & ki2ifunding.com & 2015 & $12-36 \%$ \\
\hline 7 & OMLP2P & omlp2p.com & 2016 & $10.99-36 \%$ \\
\hline 8 & Finzy & finzy.com/invest & 2016 & $10.99-27.99 \%$ \\
\hline 9 & $\begin{array}{l}\text { PaisaDukan } \\
\text { (BigWin Infotech) }\end{array}$ & $\begin{array}{l}\text { bigwininfotech. } \\
\text { com }\end{array}$ & 2018 & $12-24 \%$ \\
\hline 10 & Lendenclub & lendenclub.com & 2015 & $12-35 \%$ \\
\hline 11 & Liquiloans & liquiloans.com & 2018 & $>10.99 \%$ \\
\hline
\end{tabular}

Interest rates are per annum (unless specified otherwise) and based on the riskiness of loans. Data compiled from list of NBFC-P2P companies registered with Reserve Bank of India as on March 27, 2019.

otherwise rely on money lenders for credit, paying exorbitant interest rates. Notably, participation from women (as fundraisers and investors) has been increasing in the recent past. From 2013 to 2017, P2P platforms in India included nearly USD 195 million in overall market volume, of which USD 33.19 million were for business purposes (see Fig. 13.1 and Table 13.4).

\section{Regulations}

Regulations largely depend on the type of crowdfunding. Like most of the other countries, there are no bespoke regulations for donation and reward-based crowdfunding in India. Since there is no financial return involved in these models, they fall outside the purview of regulators like the securities market and the central bank. However, they come under the ambit of other regulations related to the payment of donations (e.g. Income Tax Act 1961) and campaign content (e.g. Information Technology Act 2000). Both individuals and organizations can run 
campaigns on these non-financial return crowdfunding platforms. However, only Indian nationals holding an Indian bank account can raise funds. For non-profit entities to receive contributions from abroad, an FCRA (Foreign Contribution Regulation Act) approval is mandatory. Yet with equity and lending-based crowdfunding, the situation is quite different.

All types of money lending are regulated by the central bank of Indiathe Reserve Bank of India (RBI). Although P2P lending came to India in 2014, there was no specific regulation in place until the latter half of 2017 (Menon 2016). In 2017 RBI issued directions targeting 'NonBanking Financial Companies' and specifically P2P lending platforms. These directions require all P2P lending platforms to obtain a certificate from RBI, while also limiting the financial services that such platforms can provide and the amount of money they can manage (e.g. maximum INR 5 million per lender and INR 50,000 to the same borrower). Additionally, the regulations do not open for the international flow of funds.

The securities market regulator, SEBI's Consultation Paper on Crowdfunding in India (2014), proposed a framework for raising of funds by start-ups and SMEs, through online crowdfunding platforms or websites. The proposed guidelines restrict both who are eligible to become equity crowdfunding platforms (e.g. recognized stock exchanges, SEBIregistered depositories, associations and networks of investors), who can receive funding through these platforms (i.e. early-stage start-ups/SMEs $<4$ years old) and how much a company can raise (i.e. <INR 100 million/12 months).

\section{Future Prospects}

Although the ideology of crowdfunding in India traces back to the Vedic period (1500-1100 BCE), online crowdfunding is still in a somewhat nascent stage. Compared to matured markets like China, USA, UK, and Europe, there is a big gap in terms of awareness, education, acceptance, and usage of crowdfunding. In the 2013-2017 period, the Indian crowdfunding volume reached USD 450 million, which is only a fraction of the 
potential indicated by the World Bank (The World Bank 2013). However, the industry has seen tremendous growth with a volume of USD 268 million in 2017 alone, and year-on-year growth of 116\% (Ziegler et al. 2018).

The significant growth rate can be attributed to socio-economic inequality, financial exclusion, unmet financial demand (credit gap), along with various other factors. The growth of non-financial return or community-based crowdfunding is driven by an increase in charity and philanthropy among people in India, a rise in foreign donations, and support for new and innovative causes. Growth in peer-to-peer lending is related to the credit gap and unbanked population. Finally, growth in equity crowdfunding can be explained by a combination of factors, and partly by the exponential growth in start-ups and SMEs. Yet, there are also several factors hindering the further expansion of the crowdfunding market.

The lack of regulatory guidelines for crowdfunding in general and equity crowdfunding, in particular, is likely hindering the growth and prospects of the industry. The industry needs to be supported by concrete guidelines in order to secure the interests of both platforms and platform users, as well as the society in general. For this purpose, inferences could be drawn from the UK's FCA regulations for investment-based crowdfunding and JOBS Act from the USA. Considering a few companies have already been crowdfunded by equity-based platforms in India, the perspective of these key stakeholders could also be considered in framing the guidelines.

Although crowdfunding in India is already covering a wide array of sectors, there still exists a number of areas that could benefit from the concept. Examples include agriculture, legal, real estate, and politics. Even though real estate and political crowdfunding have taken off recently, lessons could be drawn from developed markets like the Middle East and the USA, for its future prospects. Having one of the largest agricultural markets in the world, India could most likely benefit from agricultural crowdfunding, which is quite popular and successful in Nigeria and other African countries. 


\section{Crowdfunding in Bangladesh}

\section{History}

Bangladesh, similar to India, has a long history of crowdfunding-like approaches to donation and collection of money. Bangladesh is home to Nobel laureate Dr Muhammad Yunus, known for initiating the concept of 'microfinance' which involves lending small amounts of money to a large number of people with the purpose of alleviating poverty (Kickul et al. 2012). Another example is the so-called Somity concept, which refers to an informal co-operative where a group of people (particularly women) save together a portion of their salary or a household income that is later invested in a business (Scheyvens 2002). Somity is identical to the 'Chit Fund' concept in the Indian context. Also, during the two Eid festivals, large sums of money are donated by Muslims in the country to people in need (the concepts of zakat and sadaqah as mentioned earlier). Today, there exist crowdfunding platforms relying on the concept of Muslim donations (e.g. www.launchgood.com).

There are several examples of informal crowdfunding from Bangladesh. In 2012, when the government of Bangladesh decided to finance the Padma Bridge project (budget USD 6.7 billion, currently under construction) from domestic sources, they invited all the citizens of Bangladesh to contribute financially by donating any amount of money to designated bank accounts (Bdnews24 2012). Another example is the Rohingya refugee crisis in 2017 when a large number of people from all over the world contributed small sums of money to help people fleeing from Myanmar (UNHCR 2017). Also, collecting money from the crowd is a common way to fund medical treatment of people in need, and aid people in rural areas during the annual periods of natural calamities like floods and cyclones. Both individuals and NGOs use these types of collections.

With the help of digitalization, such activities of raising funds are now largely done via the internet, for instance through local Facebook groups such as Mastul Foundation, Donate Bangladesh, and Biddanondo. Some of these Facebook groups are aiming to move their activities to donationbased crowdfunding platforms in the near future. The JAAGO 
Foundation, a civil society organization that promotes the education of the deprived children of the country, also uses a dedicated donation webpage (donate.jaago.com.bd) to raise funds. Meanwhile, the first Bangladeshi crowdfunding platform, Projekt.co, was launched in 2015.

\section{Prevailing Models and Platforms}

As can be seen in Table 13.1, the crowdfunding scenario is rather limited in Bangladesh compared to other South Asian countries. Only USD 10,272 was reported for Bangladesh in Ziegler et al. (2018), while the number is USD 268,579,820 for neighbouring country India and USD $8,571,762$ for Pakistan. Indeed, India is a larger market than Bangladesh, but Pakistan has a similar market size in terms of population. These numbers, together with the history of informal crowdfunding in Bangladesh, indicate a vast untapped potential.

For a country with more than 160 million inhabitants and a longrooted history of donation and helping others, the possibilities of crowdfunding are still largely underexplored. In an online survey conducted by the authors, among 253 Bangladeshi respondents, 33.20\% had never heard about crowdfunding before participating in the survey. Similarly, Adhikary et al. (2018) conducted a physical survey in small Bangladeshi cities and found that only $5 \%$ of the 270 small business owners that were surveyed had heard of crowdfunding. Despite the low levels of crowdfunding awareness, people generally show a positive attitude towards using crowdfunding. About $78.6 \%$ of 253 respondents in the survey by the authors and $84 \%$ of 270 respondents in the survey by Adhikary et al. (2018) indicate that they would like to use a Bangladeshi platform. Consequently, the concept of crowdfunding seems to be poorly diffused in the Bangladeshi context.

The first crowdfunding platform in Bangladesh, Projekt.co, was inaugurated in 2015 as a reward-based platform focusing on the creative industries such as music, arts, and technology. The platform was, however, closed down in 2017 due to the lack of popularity of crowdfunding in Bangladesh. Another platform, donation-based GoRiseMe, was initiated in 2015. GoRiseMe is still in operation and has accommodated 33 campaigns since inception (GoRiseMe 2019), indicating that Bangladeshi 
people are getting familiar with the concept of crowdfunding. However, they have yet to achieve a successful campaign.

In 2018 two new platforms started their journey-oporajoy.org and fundsme.com.bd. Oporajoy is a donation-based platform and has successfully funded one campaign so far. The campaign raised about USD 150 to help a student pay for admission fees at the University of Dhaka. In total, 38 backers donated to support the campaign. Noteworthy, Oporajoy has been operating informally in Bangladesh for a few years before launching as a formal digital crowdfunding platform. Before 2018, the founder of Oporajoy was posting fund requirements for medical treatment on social media and a simple website. She has been collecting donations via cash, cheque, bank deposit, and mobile banking (e.g. Bkash), in order to support medical patients. This is an example of business model adaptability based on the context. Payment through online gateway has only recently become popular in Bangladesh. Thus, in 2018, Oporajoy transformed its operation to a modern-looking crowdfunding website with online payment gateway accommodating all possible payment mediums in the Bangladeshi context.

Today, a few crowdfunding platforms exist in Bangladesh, although with limited activity and success so far. Fundsme, which is an equitybased platform, is a sister firm of BD Venture Limited-one of two functioning venture capital firms in Bangladesh. The Fundsme project is partially funded by the Department for International Development of the UK. Despite having several published campaigns, Fundsme has not successfully funded any campaigns so far. Currently, there are no peer-topeer lending platforms in Bangladesh, and no functioning reward-based platform, although Banglafunding.com is expected to launch as a rewardbased platform in the near future. Table 13.5 summarizes key information on current and former crowdfunding platforms in Bangladesh.

Table 13.5 Crowdfunding platforms in Bangladesh

\begin{tabular}{|c|c|c|c|c|}
\hline Platform & Website & Model & Foundation & Commission \\
\hline Projekt & projekt.co & Reward & 2015 & N/A \\
\hline GoRiseMe & $\begin{array}{l}\text { goriseme. } \\
\text { com }\end{array}$ & Donation & 2015 & $\begin{array}{l}3 \% \text {, for Paypal } 3.4 \%+€ 0.35 \\
\text { per donation }\end{array}$ \\
\hline Fundsme & $\begin{array}{l}\text { fundsme. } \\
\text { com.bd }\end{array}$ & Equity & 2018 & $\begin{array}{l}\text { Upfront fee on the funding } \\
\text { goal }\end{array}$ \\
\hline Oporajoy & oporajoy.org & Donation & 2018 & $5 \%$ \\
\hline
\end{tabular}


While the Bangladeshi crowdfunding platforms have had limited success so far, many Bangladeshi campaigns were successfully funded on international crowdfunding platforms like Kickstarter, IndieGoGo, and GoFundMe. As of May 2019, searching for the word 'Bangladesh' reveals 37 campaigns on Kickstarter, 71 on IndieGoGo, and 1714 on GoFundMe. Many of these campaigns raised $100 \%$ of their pledged amount, indicating potentials of crowdfunding in the context of Bangladesh. United Nations Development Programme (UNDP) Bangladesh has also executed several successful crowdfunding campaigns to support multiple causes such as Youth Empowerment through Skills (YES) (UNDP Asia and the Pacific 2016) and farmers' access to international markets (Dhaka Tribune 2017).

\section{Regulation}

There are ongoing discussions on the need for a legal framework on crowdfunding in Bangladesh (The Financial Express 2018). Despite the existence of several platforms, no such framework exists so far. Dr Habib, a professor and director of the Bangladesh Institute of Bank Management (BIBM), argued that lack of policy and regulatory framework is making it difficult to explore the potential of crowdfunding in Bangladesh (The Financial Express 2019). Due to extensive bureaucracy, the formation of such legal frameworks typically takes many years in the Bangladeshi context. However, in an informal telephone interview, a founder of a Bangladeshi crowdfunding platform expressed positive signals towards the development of a legal framework in the near future for crowdfunding in Bangladesh.

Meanwhile, similar to the Indian context, donation and reward-based platforms can be operated without any dedicated regulation. Rewardbased platforms come under the Information and Communication Technology (ICT) Act 2006, which was enacted to facilitate e-commerce and encourage the growth of information technology. The ICT Act was later amended in 2013 and included provisions for imprisonment and/or fines for cyber-crimes (Export.gov 2018). Equity and peer-to-peer lending platforms, however, require governmental action as soon as possible. 


\section{Future Prospects}

Based on the trends in the Indian and other South Asian markets, and the culture and history of monetary contributions among the population, crowdfunding appears to be a well-suited funding option for Bangladesh. Yet, among the Bangladeshi crowdfunding platforms, there was only one valid and successful crowdfunding campaign. Also, crowdfunding seems to be relatively unknown among Bangladeshi people, indicating a need for training and awareness in order for crowdfunding to become a viable funding option. In this vein, future research should investigate the barriers of crowdfunding in Bangladesh and how to overcome them.

Lack of regulatory guidance is one of several possible barriers. Assuming some similarity among the Indian and Bangladeshi market, P2P crowdfunding is a particularly relevant model for Bangladeshi alternative finance market (also in line with Adhikary et al. 2018). Given that lending and equity-based crowdfunding are dependent on regulatory interference, Bangladeshi financial authorities are required to act in order to realize the inherent potential of crowdfunding in the country. As no P2P lending platform exists in Bangladesh, establishing such platforms is likely another important enabler for crowdfunding growth in Bangladesh.

Future research should further investigate backers' investment intention in the Bangladeshi context. Hasan et al. (2018) find that technological awareness and subjective norms positively influence backers' crowdfunding intentions. Besides, Munim et al. (2020) find that liking the campaign idea and positive media coverage increases backers' likelihood of investing in a campaign. Thus, crowdfunding platforms should make sure that campaigns published in their website are innovative and appealing. Platforms and campaign owners need to promote their campaigns in media channels such as newspaper, radio, and TV to increase the success rate.

\section{Conclusion}

Both India and Bangladesh represent interesting crowdfunding markets due to the compatibility between the principles of crowdfunding and their cultures of giving, combined with their large and relatively poor 
populations. Although crowdfunding in India is in its infancy compared to developed markets like the USA, UK, and China, India is responsible for $96 \%$ of the alternative finance volume in the South Asia region. Indian crowdfunding platforms include all the major types of crowdfunding, with lending-based platforms being responsible for the majority of the volume. Bangladesh, together with Bhutan, is the least developed alternative finance markets in South Asia. So far, there are few platforms, and the ones that exist have limited volume and success. Yet, multiple Bangladeshi campaigns have been successful on international crowdfunding platforms, indicating a positive trend also in Bangladesh. Although at drastically different stages of development, India and Bangladesh share a vast unrealized potential with respect to the opportunities of future crowdfunding industry development.

Regardless of the significant deviation in volume, both Indian and Bangladeshi crowdfunding markets are contextually similar, at the same time, unique in comparison to other parts of the world. For instance, donation-based crowdfunding volume ranks second in India and the most popular in Bangladesh. In contrast, donation-based crowdfunding by volume and popularity ranks much lower in the North American and European contexts. Unlike many other parts of the world, contextually modified dedicated women-centric platforms, chit funds, and e-commerce-based crowdfunding models are visible in both India and Bangladesh. The relatively high share of donation-based crowdfunding activity could be attributed to the collectivist culture, the high degree of religiosity, and the socio-economic situation. These potential explanations could all motivate future research on crowdfunding in South Asia.

For both India and Bangladesh, regulatory issues and sustainability of crowdfunding platforms have been a crucial issue that needs to be studied further. For equity-based crowdfunding, Kshetri (2015) proposes that a "clear regulatory framework that balances the interests of entrepreneurs and investors reduced uncertainty" (p. 106). Local or international professional organizations such as National Crowdfunding Associations (NCFAs), the World Bank, or USAID can provide support to improve the crowdfunding ecosystem (Kshetri 2015; Adhikary et al. 2018). In sum, alternative finance, in general, and crowdfunding activity, in particular, are growing in both countries, although a vast unmet potential remains. 


\section{References}

Acharya, N. (2013). Unregistered Chit Funds Having a Field Day. Business Standard. Retrieved May 22, 2019, from https://www.business-standard. $\mathrm{com} /$ article/finance/unregistered-chit-funds-having-a-fieldday-110072500020_1.html.

Adhikary, B., \& Kutsuna, K. (2016). Small Business Finance in Bangladesh: Can 'Crowdfunding' be an Alternative? Review of Integrative Business and Economics Research, 4(4), 1-21.

Adhikary, B., Kutsuna, K., \& Hoda, T. (2018). Crowdfunding: Lessons from Japan's Approach. Singapore: Springer.

Baber, H. (2019a). Subjective Norms and Intention-A Study of Crowdfunding in India. Research in World Economy, 10(3), 136-146.

Baber, H. (2019b). Factors Underlying Attitude Formation Towards Crowdfunding in India. International Journal of Financial Research, $10(4), 46-54$.

Bdnews24. (2012). Banks to Open Padma Bridge Donation Accounts. Retrieved November 19, 2019, from https://bdnews24.com/business/2012/08/08/ banks-to-open-padma-bridge-donation-accounts.

Bhasin, S. (2019). Philanthropy in India Focuses on One's Roots, Progresses to the Community, and Usually Remains Low-Key. The Economic Times. Retrieved November 19, 2019, from https:/economictimes.indiatimes.com/ news/company/corporate-trends/philanthropy-in-india-focuses-on-onesroots-progresses-to-the-community-and-usually-remains-low-key/articleshow/68161607.cms.

Bornstein, E. (2009). The Impulse of Philanthropy. Cultural Anthropology, $24(4), 622-651$.

Chirputkar, A. C., Shweta, S., \& Tarkas, J. (2015). Crowd Funding as a Tool of Business Transformation to Micro Enterprises in India-A Conceptual Framework. Indian Journal of Science and Technology, 8(S4), 115-125.

Deloitte. (2017). Regulatory Sandbox, Making India a Global Fintech Hub. Retrieved May 22, 2019, from https://www2.deloitte.com/content/dam/ Deloitte/in/Documents/technology-media-telecommunications/in-tmt-fintech-regulatory-sandbox-web.pdf.

Dhaka Tribune. (2017). UNDP, GCM to Crowd-Fund for Small Farmers in Bangladesh. Retrieved May 30, 2019, from https://www.dhakatribune.com/ bangladesh/2017/09/21/undp-start-crowd-funding-small-farmersbangladesh. 
Export.gov. (2018). Bangladesh-ECommerce. Retrieved May 30, 2019, from https://www.export.gov/article?id=Bangladesh-ECommerce.

EY. (2017). The Battle for the Indian Consumer. Retrieved May 10, 2019, from https://www.ey.com/Publication/vwLUAssets/ey-the-battle-for-the-indianconsumer/\$File/ey-the-battle-for-the-indian-consumer.pdf.

GoRiseMe. (2019). Retrieved May 30, 2019, from https://goriseme.com/about. Government of India, Ministry of Micro, Small and Medium Enterprises. (2017). Annual Report 2017-18. Retrieved May 22, 2019, from https:// msme.gov.in/sites/default/files/MSME-AR-2017-18-Eng.pdf.

Gupta, G., \& Bose, I. (2019). Strategic Learning for Digital Market Pioneering: Examining the Transformation of Wishberry's Crowdfunding Model. Technological Forecasting and Social Change, 146, 865-876.

Hasan, M. R., Ahmad, M. S., Rahman, M. S., \& Islam, M. T. (2018). Exploring the Prerequisites of Institutionalizing Crowdfunding Process in Bangladesh as an Alternative Financing Option for the Startups. Global Journal of Management and Business Research, 18(1), 17-31.

Hofstede Insights. (2019). Retrieved November 18, from https://www.hofstedeinsights.com/product/compare-countries/.

Impact Guru. (2017). Key Moments in the History of Crowdfunding (So Far). In Medium (Blog), October 31. Retrieved May 22, 2019, from https:// medium.com/@ImpactGuru/12-key-moments-in-the-history-ofcrowdfunding-so-far-3f614273d 95.

Kapoor, M., Schoar, A., Rao, P., \& Buteau, S. (2012). Chit Funds as an Innovative Access to Finance for Low-Income Households. Review of Market Integration, 3(3), 287-333.

Kickul, J., Terjesen, S., Bacq, S., \& Griffiths, M. (2012). Social Business Education: An Interview with Nobel Laureate Muhammad Yunus. Academy of Management Learning \& Education, 11(3), 453-462.

KPMG. (2018). Startup Ecosystem in India-Growing or Matured? Retrieved May 22, 2019, from https://assets.kpmg/content/dam/kpmg/in/ pdf/2019/01/startup-landscape-ecosystem-growing-mature.pdf.

Kshetri, N. (2015). Success of Crowd-based Online Technology in Fundraising: An Institutional Perspective. Journal of International Management, 21(2), 100-116.

Leela, V. (2016). Crowdfunding: A Study of Risk Factors. South Asian Journal of Management, 23(3), 170-192.

Marakkath, N., \& Attuel-mendes, L. (2015). Can Microfinance Crowdfunding Reduce Financial Exclusion? Regulatory Issues. International Journal of Bank Marketing, 33(5), 624-636. 
Menon, S. (2016). Crowd Control: Sebi Warns Turns Off Crowdfunding Tap for Startups. The Economic Times. Retrieved May 22, 2019, from https:// economictimes.indiatimes.com/small-biz/money/crowd-control-sebi-warning-turns-off-crowdfunding-tap-for-startups/articleshow/54202702.cms.

Munim, Z. H., Shneor, R., Adewumi, O., \& Shakil, M. H. (2020). Determinants of Crowdfunding Intention in a Developing Economy Context: Ex-ante Evidence from Bangladesh, International Journal of Emerging Markets. (forthcoming)

NASSCOM. (2018). Indian Tech Start-up Ecosystem-Approaching Escape Velocity. Retrieved May 22, 2019, from https://www.nasscom.in/knowledgecenter/publications/indian-tech-start-ecosystem-2018-approachingescape-velocity.

Pa, I. A. (2018). Innovations in Financing SMEs: A Study on the Growth of Crowdfunding in India. Wealth: International Journal of Money, Banking \& Finance, 7(3), 66-75.

PWC. (2018). Fintech Trends Report India-2017. Retrieved May 22, 2019, from https:/www.pwc.in/assets/pdfs/publications/2017/fintech-indiareport-2017.pdf.

Saleem, S. (2018). Lessons for P2P Lending in India. Live Mint, September 12. Retrieved May 22, 2019, from https://www.livemint.com/Money/ tuI4wvfqdbVH9nQVYC1M5I/Lessons-for-P2P-lending-in-India.html.

Scheyvens, H. (2002). Power and Poverty: The Shapla Neer Experience. Asia Pacific Viewpoint, 43(3), 329-342.

Securities and Exchange Board of India (SEBI). (2014). Consultation Paper on Crowdfunding in India. Retrieved November 19, 2019, from https://www. sebi.gov.in/sebi_data/attachdocs/1403005615257.pdf.

Srivastava, R. (2016). The Investment Model of Crowdfunding for MSME (Micro, Small and Medium Enterprises) in India. In J. Méric, I. Maque, \& J. Brabet (Eds.), International Perspectives on Crowdfunding: Positive, Normative and Critical Theory (pp. 169-184). Bingley: Emerald Group Publishing Limited.

The Financial Express. (2018). Call to Set Up Legal Framework for Crowdfunding. Retrieved May 29, 2019, from https://thefinancialexpress. com.bd/trade/call-to-set-up-legal-framework-for-crowdfunding1515647001.

The Financial Express. (2019). Crowdfunding: Developing Policy and Regulatory Framework. Retrieved May 29, 2019, from https://thefinancialexpress.com.bd/views/crowdfunding-developing-policy-and-regulatoryframework-1546440494. 
The World Bank. (2013). Crowdfunding's Potential for the Developing World. In infoDev (Ed.), World Bank. Retrieved May 30, 2013, from http://www. infodev.org/infodev-files/wb_crowdfundingreport-v12.pdf.

The World Bank. (2019). Poverty \& Equity Data Portal. Retrieved November 18, 2019, from http://povertydata.worldbank.org/poverty/home/.

UNDP Asia and the Pacific. (2016). UNDP Bangladesh Launches YES Crowdfunding Campaign. Retrieved May 30, 2019, from http://www.asiapacific.undp.org/content/rbap/en/home/blog/2016/11/28/UNDPBangladesh-launches-YES-Crowdfunding-Campaign.html.

UNHCR. (2017). Bangladeshis Race to Save Rohingya Refugees in Need. Retrieved November 18, 2019, from https:/www.unhcr.org/news/ latest/2017/10/59de1 bfb4/bangladeshis-race-save-rohingya-refugeesneed.html.

Viswanath, P., \& Dadrawala, N. (2004). Philanthropy and Equity: The Case of India. Global Equity Initiative, Harvard University. Retrieved May 14, 2019, from https://www.cbd.int/financial/charity/india-phequity.pdf.

Ziegler, T., Johanson, D., Zhang, B., Shenglin, B., Wang, W., Mammadova, L., Hao, R., Luo, D., Wang, Z., Chen, H., Alam, N., Ryu, S., Suresh, K., Jenweeranon, P., Yerolemou, N., Ryll, L., Huang, E., \& Hao, X. (2018). The 3rd Asia Pacific Region Alternative Finance Industry Report. Cambridge: Cambridge Centre for Alternative Finance.

Open Access This chapter is licensed under the terms of the Creative Commons Attribution 4.0 International License (http://creativecommons.org/ licenses/by/4.0/), which permits use, sharing, adaptation, distribution and reproduction in any medium or format, as long as you give appropriate credit to the original author(s) and the source, provide a link to the Creative Commons licence and indicate if changes were made.

The images or other third party material in this chapter are included in the chapter's Creative Commons licence, unless indicated otherwise in a credit line to the material. If material is not included in the chapter's Creative Commons licence and your intended use is not permitted by statutory regulation or exceeds the permitted use, you will need to obtain permission directly from the copyright holder.

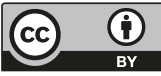

